\section{Inversion results and implications}

The global sea level variations implied by the freshwater forcing histories for the three different mixing formulations are nearly identical; each showing a drop of $\sim 15 \mathrm{~m}$ during the prolonged $\sim 3 \mathrm{kyr}$ warm phase starting around $38 \mathrm{ka}$ BP or model year 1000 . The subsequent sequence of warm-cold phases (between 35-30 ka BP) is associated with $\sim 5 \mathrm{~m}$ variations in sea level. The timing and amplitude of these sea level variations are not inconsistent with two independent reconstructions, given their uncertainties (Thompson and Goldstein, in press; Waelbroeck et al., 2002). Although the relatively large uncertainties preclude a solid conclusion, the comparison illustrates the level of accuracy that is necessary for a more stringent test of the freshwater hypothesis from the sea level record. Furthermore, these results highlight the potential importance of ice sheet growth in maintaining a negative high latitude freshwater balance for the phases of sustained warmth, with the length of the warm phases being directly related to the amplitude of the sea level fall.

The striking similarities among the three mixing formulations may be surprising considering the very different steady state response of each model to freshwater forcing (Fig. 1a). We find that the processes governing the model's transient response to freshwater forcing to be initially very similar and only begin to diverge after a few hundred years. In all cases, the imposition of a high latitude freshening reduces meridional density gradients and, hence, the strength of the meridional circulation with changes in vertical mixing lagging. A more thorough examination of the causes of this similarity is being investigated.

\section{Conclusion}

This stochastic inverse model exercise suggests that the freshwater forcing hypothesis of abrupt climate change is consistent with the most direct estimates of past sea level, assuming that (i) our interpretation of the Greenland record in terms of temperature changes in the high northern latitudes is correct, and (ii) the highly simplified model we have used captures the relevant physics. This consistency does not depend on the formulation of vertical mixing in the model. Whether more complete models are sensitive to the formulation of vertical mixing in their transient response to high latitude freshening warrants further investigation.

\section{REFERENCES}

Jackson, C. M. Sen, and Stoffa, P. 2004: An Efficient Stochastic Bayesian Approach to Optimal Parameter and Uncertainty Estimation for Climate Model Predictions, Journal of Climate, 17(14), 2828-2841.

Munk, W., and Wunsch, C., 1998: Abyssal recipes

II: Energetics of tidal and wind mixing, Deep Sea Research Part I: Oceanographic Research Papers, 45(12), 1977-2010.

Nilsson, J., and Walin, G., 2001: Freshwater forcing as a booster of thermohaline circulation. Tellus, 53A, 629-641.

Thompson, W. G. and Goldstein, S.L., in press: A radiometric calibration of the SPECMAP timescale, Quaternary Science Reviews.

Waelbroeck, C., Labeyrie, L., Michel, E., Duplessy, J.C., McManus, J.F., Lambeck, K., Balbon, E., and Labracherie M., 2002: Sea-level and deep water temperature changes derived from benthic foraminifera isotopic records, Quaternary Science Reviews, 21(1-3), 295-305.

\title{
Late Holocene hydrological variability in ombrotrophic peatlands of eastern North America
}

\author{
Stephen T. Jackson ${ }^{1}$, Robert K. Booth ${ }^{2}$, Yongsong Huang ${ }^{3}$, Elise G. Pendall ${ }^{1}$, Jonathan E. Nichols ${ }^{3}$, Thomas A. Minckley ${ }^{1}$ and \\ Meghan TayloR ${ }^{1}$ \\ 'Department of Botany, University of Wyoming, Laramie, USA; jackson@uwyo.edu \\ 2Department of Earth and Environmental Sciences, Lehigh University, Bethlehem, USA \\ ${ }^{3}$ Department of Geological Sciences, Brown University, Providence, USA
}

\section{Introduction}

Ombrotrophic peatlands, particularly "raised bogs", comprise a rich but underutilized source of Holocene paleoenvironmental records for North America. These peatlands, which are scattered from the Atlantic to the Pacific coasts at latitudes between $42^{\circ}$ and $65^{\circ} \mathrm{N}$, are dominated by Sphagnum moss and a few vascular plants, have elevated surfaces, and receive all surface moisture directly from the atmosphere. Water tables of these bogs are perched above the groundwater table, and most water loss is through evapotranspiration. Accordingly, ombrotrophic bogs are hydrologically sensitive to precipi- tation and temperature variations across a range of temporal scales, from seasonal to millennial.

Sedimentary records from ombrotrophic peats can span 1000-10,000 years, with temporal resolution ranging from sub-centennial to sub-decadal depending on accumulation rates. A variety of paleoenvironmental proxies, including testate-amoebae, peat humification, pollen, plant macrofossils, charcoal, stable isotopes $(\mathrm{H}, \mathrm{C}, \mathrm{O})$, and biomolecular markers, are preserved in these peats. We are conducting a study of all of these proxies in late Holocene peats from raised bogs along a transect spanning the Great Lakes/
St. Lawrence corridor, from Minnesota to Maine. We are coupling these paleoclimate reconstructions with extensive modern calibration studies and investigations of historical climate variability. These studies are leading to detailed multivariate climatic reconstructions and development and testing of hypotheses regarding the underlying climate dynamics.

\section{Peatland records of drought synchrony in the Central United States}

Peat records from sites $1000 \mathrm{~km}$ apart in north-central Minnesota (Hole Bog) and southeastern Michigan (Minden Bog) span the past 


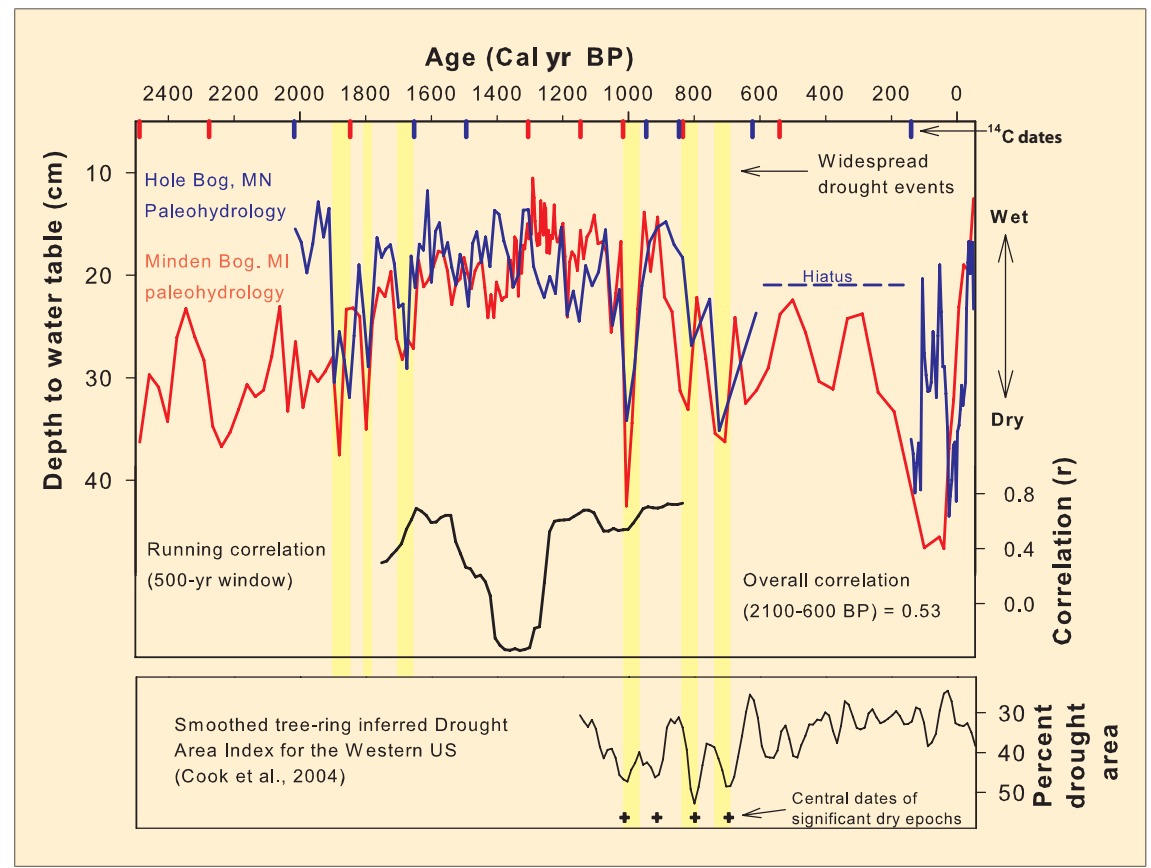

Figure 1. Paleohydrological records from ombrotrophic peatlands $1000 \mathrm{~km}$ apart in southeastern Michigan and north-central Minnesota show spatial coherence over the past 2000 years. Highfrequency patterns between 600-1000 years ago show good correspondence with tree-ring records from the Great Plains and Rocky Mountains to the West. The blue trace represents the Minnesota record and the red trace the Michigan record, both expressed in terms of depth to water table based on multivariate analysis of testate-amoeba assemblages (see Booth \& Jackson, 2003 for details). Modified from Booth et al. (2006).

several thousand years (Fig. 1). Water-table depths inferred from testate-amoeba assemblages reveal substantial hydrological variability at decadal to sub-millennial scales, with much of this variability coherent between the two sites. Coherent fluctuations are particularly evident during time periods of high-magnitude moisture fluctuations, suggesting that large moisture fluctuations are often widespread-an observation consistent with documented patterns of widespread drought during the past century (McCabe et al., 2004; Booth et al., 2006).

The western Great Lakes region is susceptible to multi-year droughts centered in the Great Plains (e.g., the 1930s droughts penetrated eastward into the region). The high-frequency paleohydrological patterns in our bog records indicate that prehistoric multi-year to multi-decadal droughts of the Great Plains were felt at least as far east as Michigan. The Michigan and Minnesota peatlands both record severe, multidecadal droughts centered on 700, 800, and $1000 \mathrm{yr}$ BP (Fig. 1), corresponding to Medieval Warm

\section{Emerging proxies: Molecular biomarkers and compound- specific stable isotopes}

We are currently developing and applying other proxies from ombrotrophic peatlands of mid-continental and eastern North America. One new approach is the use of molecular biomarkers. For example, Sphagnum differs from vascular plants and terrestrial mosses in the frequency distribution of n-alkane chain-lengths (Nichols et al., in press); because water retention is less critical for Sphagnum, cuticle waxes tend to be constructed of shorter (and presumably more economical) alkane chains. Ecological and paleoecological studies (based on plant macrofossils) indicate that Sphagnum moss tends to be especially productive during extended wet periods, while droughts favor expansion of ericads, sedges, and other vascular plants. Stratigraphic records of n-alkane distributions from Minden Bog generally correspond to patterns inferred from testate amoebae and humification (Fig. 2). However, humification and n-alkane spectra show an apparent dry anomaly ca. $1300 \mathrm{yr}$ BP that is unrecorded by the testate amoebae. This underscores the need for multiple proxies that record different kinds of hydrological responses to different aspects of climate variation.

Another promising avenue is the identification and extraction of organic compounds specific to Sphagnum. Preliminary results indicate that 2-heptacosanone can be extracted from at least seven different species of Sphagnum but not from any vascular plants or other mosses found in peatlands. Such Sphagnum-specific biomarkers can be used not only as an index for quantifying Sphagnum productivity but also for compound-specific analysis of $\delta D$ and $\delta^{13} \mathrm{C}$, which can provide further information on moisture balance and temperature.

Sphagnum macrofossils are well preserved in all but the most humified peats. Analysis of compound-specific and taxon-specific $\delta^{18} \mathrm{O}$ (from cellulose in Sphagnum) 
can provide information on moisture balance. $\delta^{18} \mathrm{O}$ from modern Sphagnum plants is correlated with that of bog waters and with water-table depth. Ongoing analyses of $\delta^{18} \mathrm{O}$ from Sphagnum macrofossils will provide an additional proxy. Downcore analyses of compound-specific and taxon-specific $\delta D, \delta^{18} \mathrm{O}$, and $\delta^{13} \mathrm{C}$ should allow us to tease apart moisture-balance, temperature, and humidity signals in the bog records (e.g., Pendall et al., 2001).

\section{Pollen liberation: Assessing vegetational responses to climate change}

Pollen assemblages have traditionally been the primary paleoclimatological tool for continental regions at timespans longer than the past few centuries. Development of independent paleoclimate records from testate amoebae, stable isotopes, and biomarkers preserved in peatlands and other archives now allows us to use pollen data to assess vegetational responses to climate change and variability. The Minden record, for instance, demonstrates that a regional shift from beech to white pine dominance 800-1000 years ago, and an accompanying increase in fire incidence was driven by the onset of drier conditions (Booth and Jackson, 2003). This vegetational transition had been controversial, ascribed variously to decreasing temperatures or activities of indigenous peoples. We are currently developing high-resolution pollen records for selected time intervals to assess regional vegetational responses to transient climate events, and to gauge the limits of pollen sensitivity to climate change.

\section{Outlook}

Our ultimate goal is to develop a multiproxy, synoptic-scale network of paleohydrological and paleoecological records from ombrotrophic peatlands. Eventually, this network could stretch from coast to coast, and from ca. $45^{\circ}-60^{\circ} \mathrm{N}$ in North America. With such a network, Holocene climate variability can

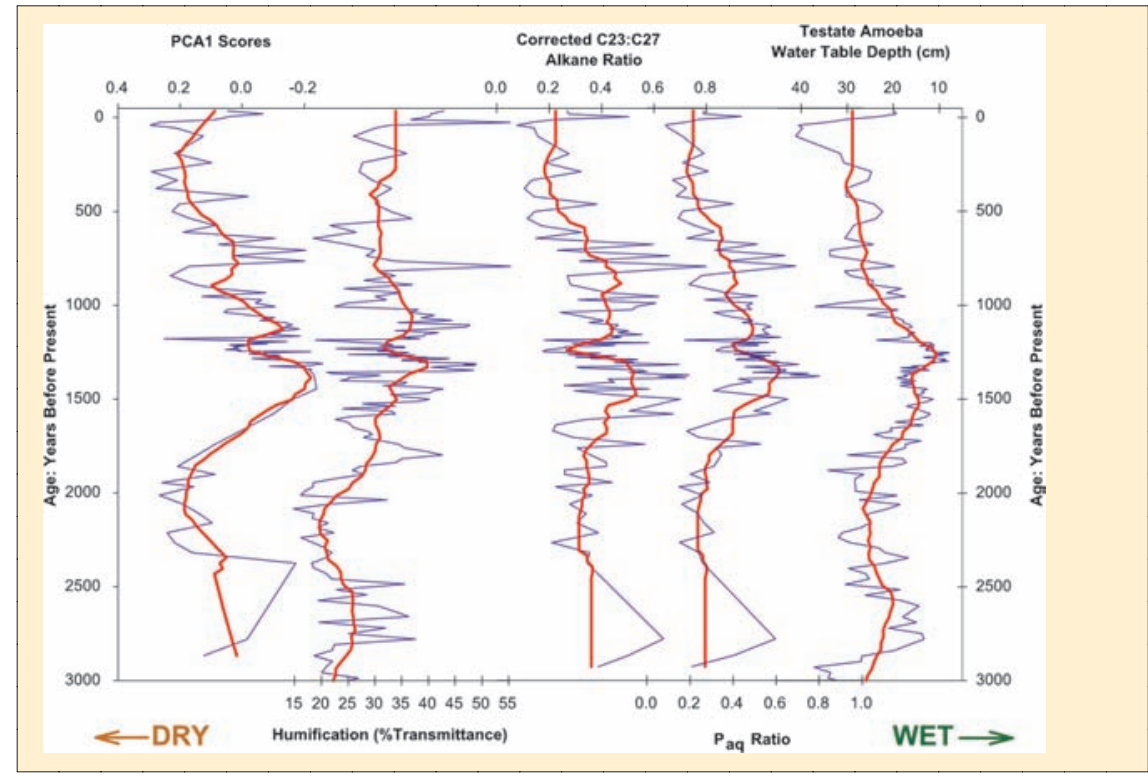

Figure 2. Different proxies from the Minden Bog (MI) record show general correspondence, with some potentially revealing contrasts. Water-table depth inferred from testate-amoeba assemblages and peat humification measured colorimetrically represent two conventional approaches to peatland sediments (see Booth and Jackson, 2003). Different expressions of $n$-alkane ratios from the sediments represent indices of relative biomass of Sphagnum and other plants. In all five panels, moisture increases along the $y$-axis. Negative exponential smoothing has been applied to each record to emphasize broad scale correlation. Modified from Nichols, et al. (in press).

be assessed at timescales ranging from multi-decadal to millennial. Spatiotemporal patterns of variability within the network, and between bog records and other archives (tree-ring, lake-level, aeolian, glacial) should provide a basis for assessing mechanisms governing climate change and variability. Bog-based records of climate change can also be utilized to identify climate drivers of forest and fire dynamics, inferred from pollen, macrofossil and charcoal data. European scientists are currently developing a network of bog records across Eurasia. Thus, the potential exists for a circumboreal paleoclimate network for the entire Northern Hemisphere, based on multiple proxies from peatland archives. Such a network could generate significant advances in understanding the patterns and mechanisms of Holocene climate evolution.

\section{Note}

Data used in this study will be available in the NOAA Paleoclimatology data base at: www.ncdc.noaa.gov/paleo/paleo.html For detailled information, contact the authors.

\section{REFERENCES}

Booth, R.K., and Jackson, S.T., 2003: A high-resolution record of Late Holocene moisture variability from a Michigan raised bog. The Holocene, 13:865-878.

Booth, R.K., Notaro, M., Jackson, S.T., and Kutzbach, J.E., 2006: Widespread drought episodes in the western Great Lakes region during the past 2000 years: geographic extent and potential mechanisms. Earth and Planetary Science Letters, 242:415-427.

Cook, E.R., Woodhouse, C., Meko, D.M., and Stahle, D.W., 2004: Long-term aridity changes in the western United States. Science, 306:1015-1018.

McCabe, G.J., Palecki, M., and Betancourt, J.L., 2004: Pacific and Atlantic Ocean influences on multidecadal drought frequency in the United States. Proceedings of the National Academy of Sciences, 101:4136-4141.

Nichols, J.E., Booth, R.K., Jackson, S.T., Pendall, E.G., and Huang, Y., in press: Paleohydrologic reconstruction based on $\mathrm{n}$-alkane distributions in ombrotrophic peat. Organic Geochemistry.

Pendall, E., Markgraf, V., White, J.W.C., Dreier, M. and Kenny, R., 2001: Multiproxy record of late Pleistocene-Holocene climate and vegetation changes from a peat bog in Patagonia. Quaternary Research, 55: 168-178. 